R. E. Byrd, U.S.N. The vehicle, called the Snow Cruiser, is to be used as a mobile base, and it is reported to be capable of travelling across ice fields, of climbing gradients of 35 per cent, of sliding down them on its steel-ribbed under-floor and of erossing crevasses in the ice $15 \mathrm{ft}$. wide. The Snow Cruiser is more than $55 \mathrm{ft}$. long, $20 \mathrm{ft}$. wide and $15 \mathrm{ft}$. high, and weighs, fully equipped, $33 \frac{1}{2}$ tons. It has four pneumatic-tyred wheels $10 \mathrm{ft}$. in diameter which can be turned independently to various angles, and which can also be retracted into the vehicle. The structure is of steel electrically welded, and the motive power consists of two 150 h.p. oil engines driving electric generators supplying current to the traction motors. In the interior are the living quarters, store-rooms, the engine room, a machine shop and a laboratory, and also tanks for the storage of 2,100 gallons of oil fuel and of nearly 850 gallons of petrol for the aeroplane carried on the back of the vehicle. The Snow Cruiser was designed and constructed by the Research Foundation of Armour Institute in Chicago, under the direction of Dr. T. C. Poulter, scientific director of the Foundation, who was second-in-command of the second Byrd expedition.

\section{Puffin Crosses North Atlantic}

ONE of the most important results of bird-ringing experiments is the first recovery in North America of a puffin (Fratercula arctica arctica) ringed in Europe. This was a specimen ringed by Lord Dumfries as a young bird on St. Kilda on August 10, 1939, and shot at Herring Neck on the north coast of Newfoundland on December 20, 1939 (British Birds, March 1940). The instances of European-marked birds traced to North America are very few. The most numerous records are of the kittiwake (Rissa tridactyla); specimens marked as young on the Farne Islands, Northumberland, have been recovered in autumn and winter months at Davis Strait, Labrador, and Newfoundland over periods since 1924; another specimen ringed at Khasilov Island, in the Barents Sea, was recovered at Little Fogs Island, Newfoundland. Black-headed gulls (Larus ridibundus) ringed at Rossitten, East Prussia, have been recovered in Mexico and the Barbadoes, and there is the celebrated record of Cumberland lapwings (Vanellus vanellus) shot in Newfoundland after a gale forced them from their normal migration to Ireland. Previous ringing returns of Scottish puffins have shown no marked westerly migration. Specimens from Northumberland have been recovered at Norway.

\section{Effect of Winter Frosts on Bird-life}

IN a lecture to the Hastings and St. Leonards Natural History Society on April 23, Mr. Eric Hardy described the serious effect upon the numbers of insectivorous British birds as a result of the severe frosts during the past winter, when, particularly in the north, vast numbers of thrushes, blackbirds, titmice and other birds were killed by the long absence of food and water. In recounting at length many of his ornithological studies in the north, Mr. Hardy stressed the possible effect of this partial loss of useful insectivorous birds at a time of national food-growing efforts, and the possibilities of increased wireworm damage to cornland, and cabbage white caterpillars to cultivated greens. There is a marked shortage of many of the residential insect-eating birds in woods in the north, although Nature has recovered from the severe winter toll of bird-life more rapidly than was anticipated and it will be interesting to compare the future results with previous hard winters. "Nevertheless, there is an urgent need to protect and increase insectivorous birds by providing more nesting and feeding haunts, for example, growing more undergrowth in woods and plantations, and preventing loss of existing bird haunts by river pollution and heath fires.

\section{Canada's Indian Policy}

$A_{N}$ interesting review of the circumstances and problems of the Indian population of Canada was given by Mr. Diamond Jenness of the National Museum of Canada, at the recent meeting of the American Association for the Advancement of Science at Columbus, Ohio. The Indian policy of the Canadian Government was framed at a time when to civilize in accordance with the white man's ideals, rather than to conserve, was the aim of liberal and humanitarian administration. Further, it was considered inevitable that such backward peoples would be unable to withstand the difficulties and dangers of contact with civilization and must become extinct. Hence Canadian policy was fusion of the two populations rather than segregation. The Indian was gradually to be absorbed by the white.

Of recent years, however, in Canada, as in other parts of America, the Indian population is increasing ; but a more or less successful adaptation to changed conditions, if it has not actually contributed to the increase, as is probable, has certainly averted untoward consequences. This is implied in the comment by Mr. Jenness that the Iroquoians of eastern Canada, "being an agricultural people, ... . were not forced to undergo any sudden revolution". Among the Plains Indians, in the difficult transition from buffalo hunting to growing wheat, the Blackfoot, now the most prosperous, had the advantage of being guided by able and far-sighted chiefs. The Indians of the Pacific coast, both in temperament and economy, have proved less capable of readjustment; but in the Arctic, as might be expected, the Eskimo show themselves well able to hold their own, while the women make excellent wives for the white pioneers who settle on this frontier.

\section{Bureau of American Ethnology, r938-39}

THE major field research with which the Bureau of American Ethnology was associated in the fiscal year 1938-39 (Fifty-sixth Annual Report, 1938-1939, 1940) continued to be that of the United States De Soto Expedition Commission. For the greater part of the year Dr. John R. Swanton was in the field in the interests of the Commission or engaged in the preparation of its report. With various members of the Commission he visited points in North 